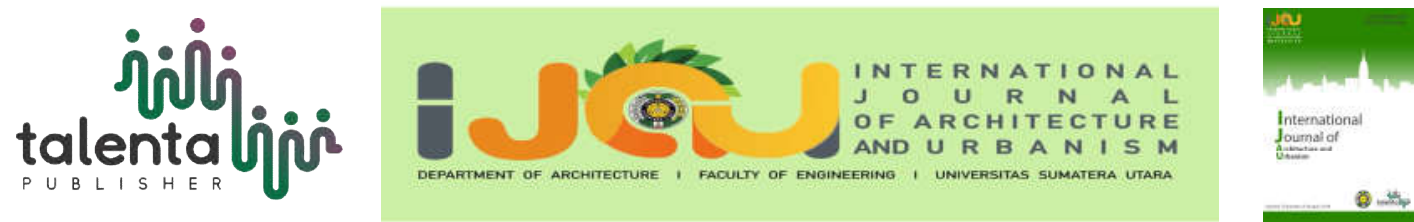

\title{
Medan Labuhan Shopping Center
}

\author{
Devin Defriza Harisdani ${ }^{{ }^{*}}$, Aidil Fahrendy ${ }^{1}$ \\ ${ }^{I}$ Department of Architecture, Universitas Sumatera Utara, Medan, Indonesia
}

\begin{abstract}
Medan Labuhan is one of the sub-districts that located in North Medan. The economy in this place is far left behind when compared to Medan City. To improve the economic condition of the region, it is necessary to build a shopping center. The shopping center is not only on the economic side but also a public space for people to do interaction and recreation. The analogy of Deli river into metaphor concept will make a new identity of this region. This shopping center will enhance economic growth, re-development of the historical potential of Medan Labuhan area as a new attraction for the people of Medan and tourists.
\end{abstract}

Keyword: shopping center, public space, recreation, historical potential, metaphor

\section{Introduction}

North Medan is a sub-city of Medan that serves the northern part of Medan. Medan Labuhan is one of 21 districts in Medan city. This district has a population of 117,472 people with an area of $40.68 \mathrm{~km} 2$. This subdistrict is located relatively far from the center of the city, causing inequality of development in this area. The inequality of development between the middle of Medan and other sub-districts, especially Medan Labuhan, has an impact on the lack of economic investment interest in this sub-district, whereas this district has great potential and history to grow. The Chinatown area of Medan Labuhan in the past several centuries is known as Labuhan Deli and is very famous for its Deli River and its trade area, but due to the displacement of power and the condition of the delinquent Deli river resulted in the decline of the trade center in this region which was once a row of shophouses nuanced architecture of China is very iconic.

To improve the quality of economy in Medan Labuhan then, it takes a shopping center. With this shopping center is expected to become an icon of the return of trade development Medan Labuhan area. The history of Medan Labuhan is expected to be translated well into the design, so this shopping center will be a new iconic feature that can describe this region with a visual impression to be enjoyed by everyone who saw it.

\footnotetext{
*Corresponding author at: Department of Architecture, Faculty of Engineering, Universitas Sumatera Utara,

Jalan Perpustakaan Gedung J07, Medan 20155, Indonesia

E-mail address: devin.defriza@usu.ac.id
} 


\section{Literature Review}

A shopping center is a group of retail and other commercial establishments that is planned, developed, owned and managed as a single party property [2]. It is run by central management that leases units to the merchant, and on certain matters, the control is performed by the manager who is fully responsible to the shopping center [1]. Metaphors identify possible patterns of parallel relationships by looking at their abstraction, in contrast to the literalist analogy [3].

\section{Methodology}

The design site selection reference is based on the Building and Environmental Management Plan of Medan Labuhan Pecinanan Area 2010-2030 (RTBL $\left.{ }^{1}\right)$. Based on the structure of the area, it is explained that the design location is in the area functioned as the trade and industrial activities, health, and transportation service center. The assessment stages in site selection and process design on the "Medan Labuhan Shopping Center" project can be elaborated through these several stages which are site data collection stage which refers to the RTBL, that based on the structure of the region that the location will be designed is a residential area with low population density medium that is not well ordered. And then pre-design stage in the form of the idea about a shopping center that can accommodate the activity of buying and selling of society in the North Medan area, especially Medan Labuhan. Then the design analysis stage by the information and data that support both of architectural and non-architectural through various libraries and media as a consideration in solving problems which including basic concept, site plan design, circulation concept, mass composition concept, pedestrian concept, plan concept, structure, and utility concept. And the final stages of the development of the design idea will be poured into the detail of the plan, section, and 3D impression.

\section{Result and Discussion}

The purpose of this shopping center design is to be able to fulfill the daily needs as well as a new recreation for the community of North Medan area, especially Medan Labuhan. Also, the design aims to increase the potential return and the history of the River Deli, to become an enhancer of the image area of this Medan Labuhan. The location of the design is located in Medan Labuhan sub-district of Pekan Labuhan and is a medium density slum. The location of this project has an overall area of about 2.1 hectares.

\subsection{Basic Concept}

The historical side of the region is the main objective of the basic concept of design. The application of the historical side of this area into the building aims to make this shopping center can be a new image and identity, especially Medan Labuhan. Therefore, the building applies

${ }^{1}$ RTBL:Rencana Tata Bangun dan Lingkungan (Building dan Environmental Management Plan) 
the theme of Metaphor to analogize the historical side into the building. Medan Labuhan Shopping Center analogized the element of water as a metaphor; it is a simplification of the form and meaning of one side history of the Deli River. The application of the water element into the building will focus on mass formation as well as for visitors to enjoy this building from inside and outside (visual)

\subsection{Exterior/Siteplan Design}

The position of the building is located at the crossroads, so to respond it is designed pedestrian flow and green space on two sections of the road Syahbudin's street and Sudarso's street intersection (Figure 1). Medan Labuhan has a rich story of the trade area, leaving the cultural heritage of Chinatown along Syahbudin's street. With this housing, it is guided to form an outer space that is responsive to this potential. Then as respond to this heritage potential is designed a pedestrian along the road that directly adjacent to it as an open space to the public (Figure 2). Open space is also a spot of functional activities that bring people into a routine normal daily life as well as in periodic activities [4].

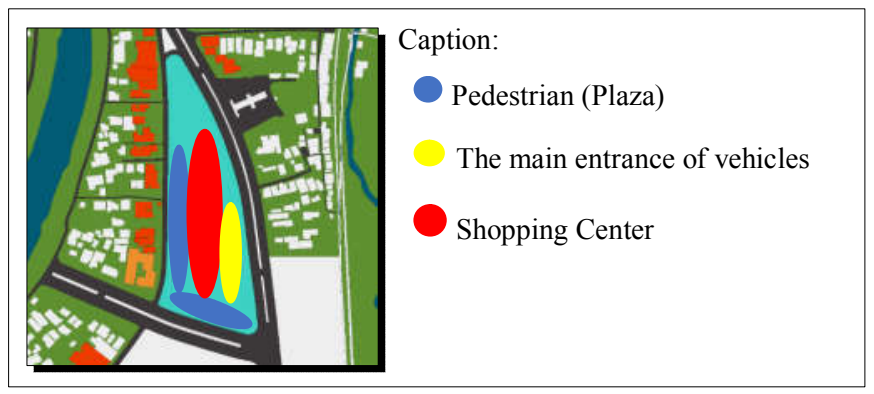

Figure 1. Exterior/Siteplan Design

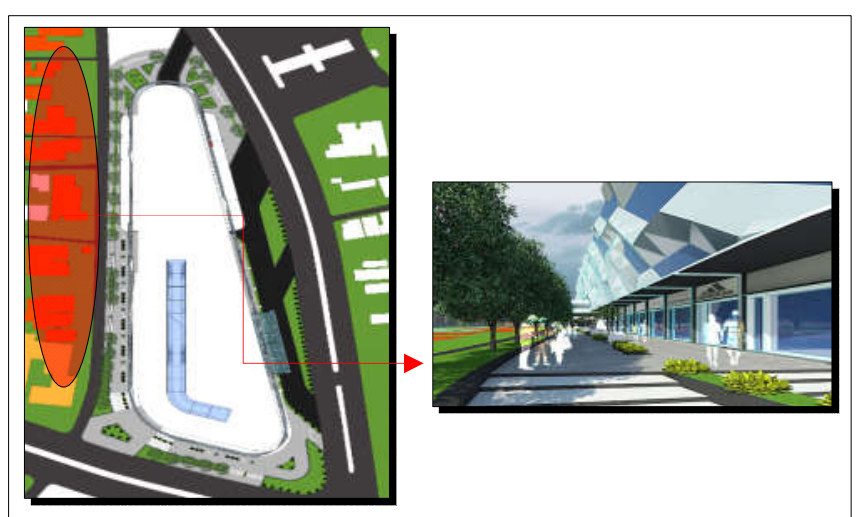

Figure 2. Pedestrian as respond to the ancient shop across the road

\subsection{Circulation Concept}

On the Sudarso's street is designed as the main line of vehicles to enter into the site. While on the site adjacent to Shahabuddin's street is designed as a pedestrian or plaza path as a response 
to the existing ancient shopping buildings that can be enjoyed by visitors or pedestrians (Figure $3)$.

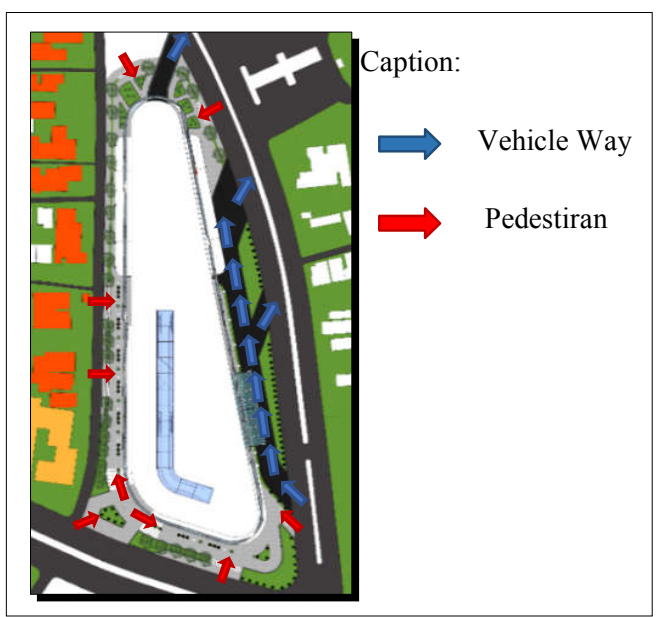

Figure 3. The Concept of Circulation/Achievement

\subsection{Pedestrian Concept}

Pedestrian and green space is formed in such a way following the existing site formation and done to maximize the area is narrow. The building footprint level is higher than the roadside. It is necessary to access stairs from each side of the site (bordering the road) to pedestrians (Figure $4)$.
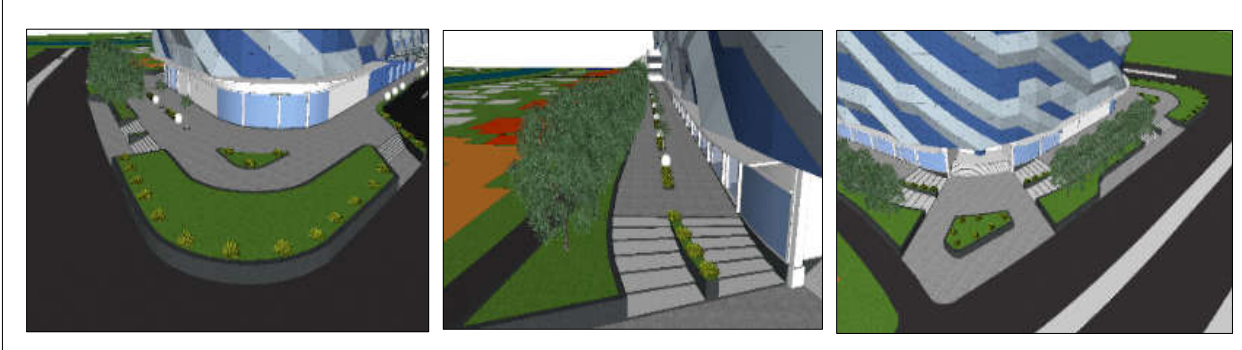

Figure 4. Pedestrian Concept

\subsection{Mass Composition Concept}

This shopping center analogized the element of water as its facade. The building is done so that the immigrants and visitors can feel and enjoy visually both from near or far. The applied analogy is a falling form of water (Figure 5). Also, to respond to sunlight on the longest side of the building (front), then in this section is made to buffer (shading) to be a filter to direct sunlight (Figure 6). 


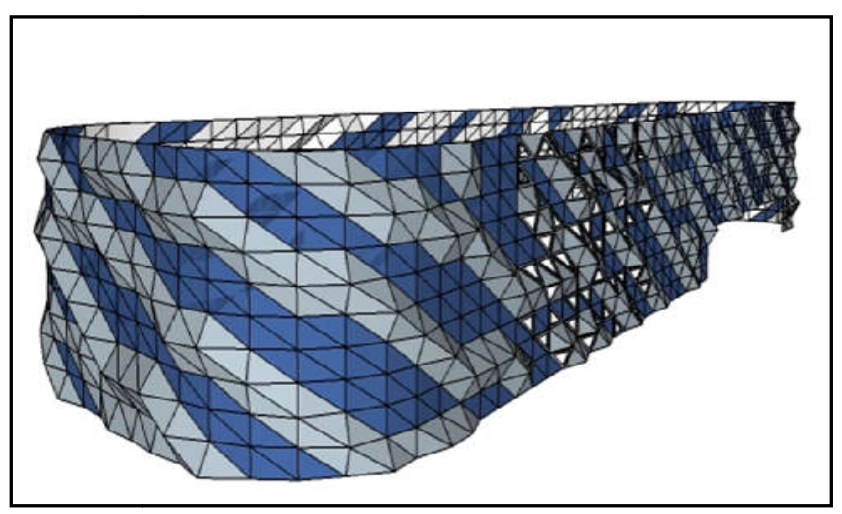

Figure 5. Water Spots Analogy on Façade

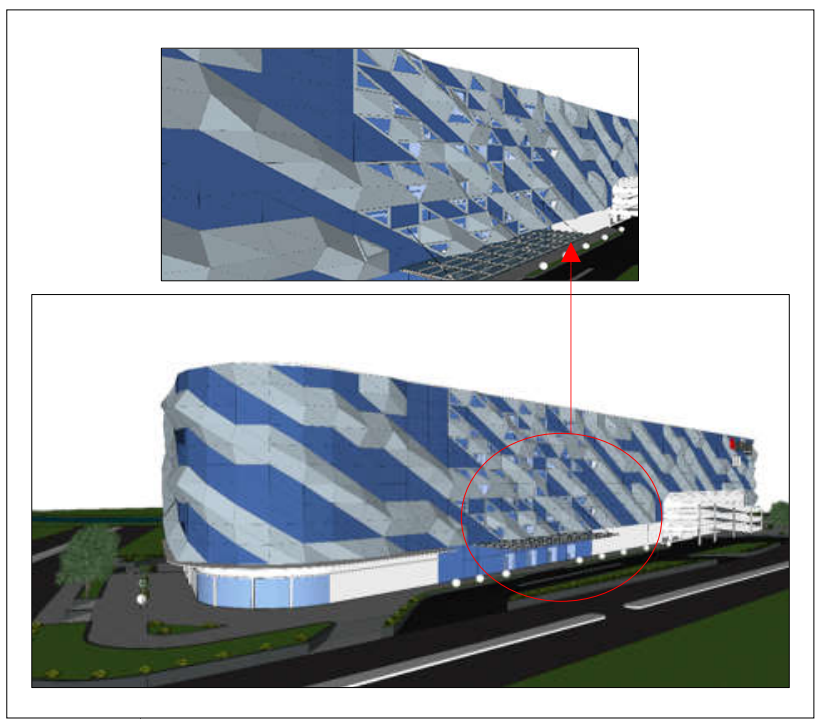

Figure 6. Buffer for filters against excessive direct sunlight

\subsection{Concept of Inner Space Permit}

The retail structure is arranged along the building formation to maximize the area of the building and the rental area (Figure 7).

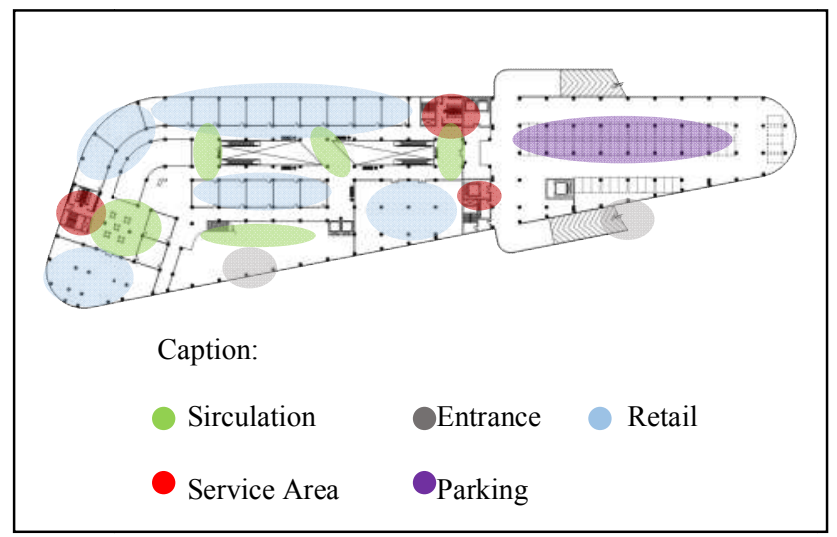

Figure 7. Concept of Inner Space Permit 


\subsection{Structure Concepts}

In Medan Labuhan Shopping Center uses Rigid Frame structure system in which the system is more focused on the grid system. With the use of the grid system will form a pattern of the room is neatly arranged, making it easier for the placement of large quantities in the retails (shops). The rigid frame is strong and good enough structure with a 5-story building and facilitates the pattern of car parking places (Figure 8).

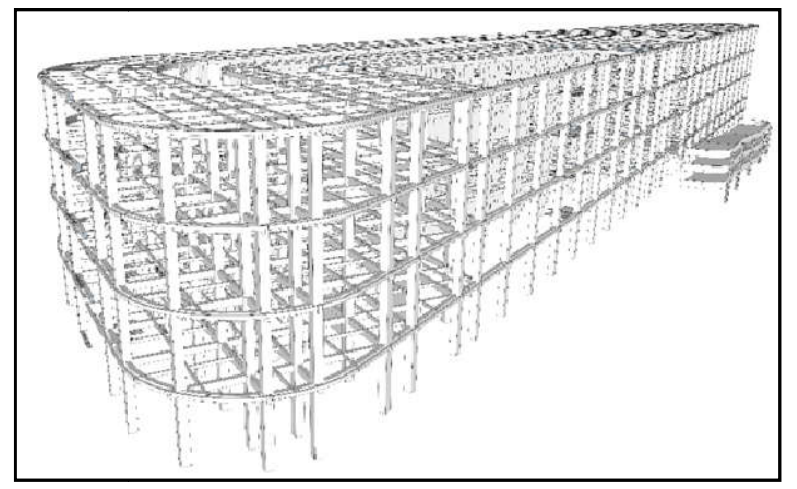

Figure 8. Rigid Frame Structure

\subsection{Utility Concepts}

For this shopping center water supply comes from $\mathrm{PDAM}^{2}$ or artesian wells. The working system that is clean water from PDAM or artesian well into the distribution and accommodated in the ground reservoir then flowed into the building (Figure 9). Before discharge to the city sewer, dirty water must pass through the treatment process first and then distributed to the septic tank and absorption wells (Figure 10).

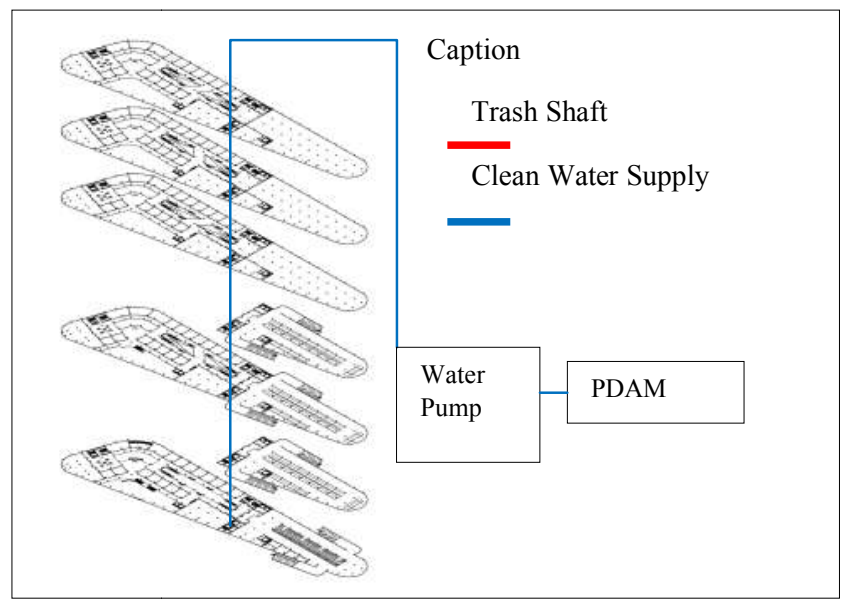

Figure 9. The Concept of Clean Water Supply System

\footnotetext{
${ }^{2}$ PDAM:Perusahaan Daerah Air Minum (Local Water Company)
} 


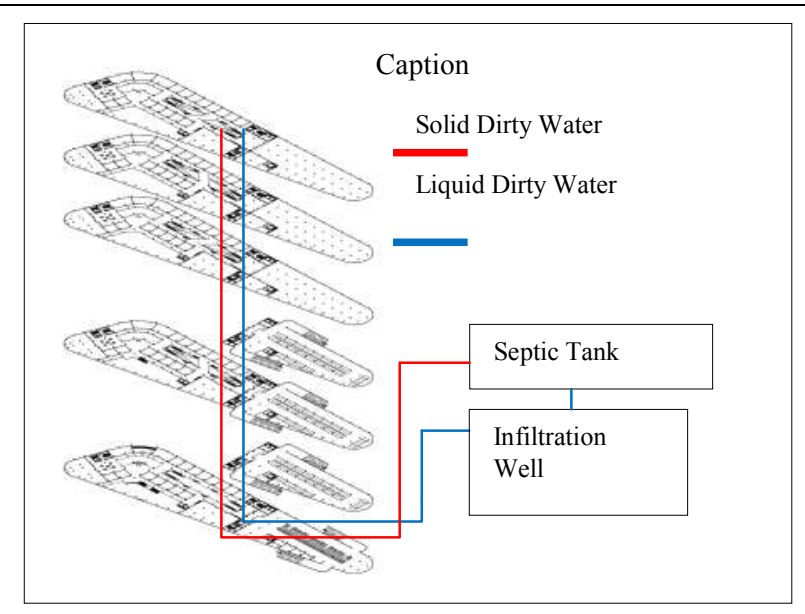

Figure 10. Concept of Dirty Water Distribution

\section{Conclusion}

The purpose of this shopping center design is to meet daily needs and also become a place of recreation for the people of North Medan area, especially Medan Labuhan. This shopping center will also be a container of potential re-development of Medan Labuhan trading area to be active again as in ancient times where this district is one of the Medan city's trade skill is quite active. To meet the recreational needs, the application of the metaphor theme is the most appropriate choice. Deli River on the concept of metaphor will make this shopping center a new identity of this area and become the pride of the people of North Medan, especially Medan Labuhan.

\section{Acknowledgment}

This research is part of the requirement to obtain a bachelor's degree in the Architecture Department of Universitas Sumatera Utara.

\section{REFERENCES}

[1] N. Beddington. Design for shopping centres. Butterworth-Heinemann. 1982.

[2] I. S. C. Definitions. International council of Shopping Centers. New York. 2013.

[3] A. J. Catanese \& J. C. Snyder. Pengantar Arsitektur. Jakarta: Erlangga. 1991.

[4] S. Carr. Public space. Cambridge University Press. 1992. 